OPEN ACCESS

Citation: F. Dotti do Prado, A. Abrigato de Freitas Mourão, F. Foresti, J. Augusto Senhorini, F. Porto-Foresti (2021) First cytogenetic characterization of the Amazon Catfish Leiarius marmoratus (Gill, 1870) and its hybrid with Pseudoplatystoma reticulatum (Eigenmann \& Eigenmann, 1889). Caryologia 74(1): 127-133. doi: 10.36253/caryologia-1149

Received: December 03, 2020

Accepted: April 26, 2021

Published: July 20, 2021

Copyright: (c) 2021 F. Dotti do Prado, A. Abrigato de Freitas Mourão, F. Foresti, J. Augusto Senhorini, F. Porto-Foresti. This is an open access, peer-reviewed article published by Firenze University Press (http://www.fupress.com/caryologia) and distributed under the terms of the Creative Commons Attribution License, which permits unrestricted use, distribution, and reproduction in any medium, provided the original author and source are credited.

Data Availability Statement: All relevant data are within the paper and its Supporting Information files.

Competing Interests: The Author(s) declare(s) no conflict of interest.

ORCID

FDP: 0000-0002-4189-0375

FF: 0000-0002-0862-0445

FPF: 0000-0001-8845-3845

\section{First cytogenetic characterization of the Amazon Catfish Leiarius marmoratus (Gill, 1870) and its hybrid with Pseudoplatystoma reticulatum (Eigenmann \& Eigenmann, 1889)}

\author{
Fernanda Dotti do Prado ${ }^{1}$, Andrea Abrigato de Freitas Mourão 2 , \\ Fausto Foresti ${ }^{3}$, José Augusto Senhorini ${ }^{4}$, Fábio Porto-Foresti ${ }^{1, *}$ \\ ${ }^{1}$ Faculdade de Ciências, Universidade Estadual Paulista Júlio de Mesquita Filho, Av. Eng. \\ Luiz Edmundo Carrijo Coube, 17033-360, Bauru, São Paulo, Brazil \\ ${ }^{2}$ Universidade Paulista - UNIP, R. Luís Levorato, 140, 17048-290, Bauru, São Paulo, \\ Brazil \\ ${ }^{3}$ Instituto de Biociências, Universidade Estadual Paulista Júlio de Mesquita Filho, Distrito \\ de Rubião Júnior, 18618-970, Botucatu, São Paulo, Brazil \\ ${ }^{4}$ Centro nacional de pesquisa e conservação da biodiversidade aquática continental - \\ CEPTA, Rodovia SP-2, 01 (Pref. Euberto Nemésio Pereira de Godoy), 13.630-970, Piras- \\ sununga, São Paulo, Brazil \\ *Corresponding author. Email: fp.foresti@unesp.br
}

\begin{abstract}
This study reports the first cytogenetic characterization of the Amazonian catfish Leiarius marmoratus ("jandiá") and its $\mathrm{F}_{1}$ (first generation) hybrid "cachandiá" with Pseudoplatystoma reticulatum ("cachara"). A diploid number of 56 chromosomes and a single argyrophilic nucleolus organizer region (Ag-NOR) in the short arm of two sub-telocentric chromosomes were observed for both L. marmoratus and P. reticulatum, but with differences in the karyotype formula and the size of the chromosome pair with NORs. The hybrid showed $2 \mathrm{n}=56$ chromosomes with an intermediate karyotype when compared to the parental species. A single Ag-NOR was maintained in the hybrid but located in two chromosomes with marked differences in size and presenting intraindividual variation in NOR activity (nucleolar dominance). For L. marmoratus and the hybrid, heterochromatic bands were predominately distributed in the terminal, centromeric, and sub-centromeric regions of some chromosomes and 5S rDNA sites located in two distinct sub-telocentric chromosomes, similar to the previously described for $P$. reticulatum. The data suggested that the hybrid karyotype might be insufficient for a precise discrimination of hybrids, however, Ag-NOR can be used as a chromosome marker to differentiate "cachandiá" from L. marmoratus and P. reticulatum. The current study also provides insights into the chromosomal features of L. marmoratus and contributes with novel cytogenetic information of this native Amazonian catfish included in the Pimelodidae family.
\end{abstract}

Keywords: Pimelodidae, Hybrid karyotype, Cachandiá, Pintado da Amazônia, Yaque, Ag-NOR. 


\section{INTRODUCTION}

The long-whiskered catfish Leiarius marmoratus belongs to the Pimelodidae family, (Teleostei: Siluriformes) (Lundberg and Littmann 2003) and is an endemic species that naturally occurs along the Amazon and Orinoco River basins. This fish is commonly known as "jandiá", "jundiá amazônico", "peixe-onça" in Brazil (Porto-Foresti et al. 2013), and "yaque" in other Andine countries (Mateo et al. 2008). Widely used in aquariums and local fisheries, L. marmoratus is also cultivated in Brazilian aquaculture to produce interspecific hybrids with the "cachara" catfish (Campos 2010, Hashimoto et al. 2012; Hashimoto et al. 2016). The "cachara" correspond to other native South American Pimelodidae fish classified as Pseudoplatystoma fasciatum (sensu latu) in the Amazon area or P. reticulatum (sensu strictu) in southern regions of South America as the Paraguay and Parana River basins (Buitrago-Suarez and Burr 2007).

The hybrids between $L$. marmoratus and $P$. reticulatum are usually named as "cachandiá", "cachadia" or "jundiara" (Kubitza et al. 2011, Porto-Foresti et al. 2013) and are commercialized in the Southern regions of Brazil as "pintado da Amazônia", "pintado amazônico" or simply "pintado" (Kubitza et al. 2011). Morphological data indicated that, spite with intermediate characteristics, these hybrids can externally resemble more to $P$. reticulatum (Coelho et al. 2021). Although the hybridization practice can provide economic advantages during the production as low cannibalism and fast growth rates, accidental escapes or intentional releases of hybrids in the wild environment represents a serious problem, since they can present partial or total fertility and cause genetic introgression with native populations (Yabu et al. 2018).

Despite the large biodiversity of fish found in the tropics, information is still lacking for several species and there is no cytogenetic data for any species of Leiarius including L. marmoratus. In this study, we performed the first cytogenetic characterization of L. marmoratus and its hybrid "cachandiá" with $P$. reticulatum, and thereby provide new biological information of this important group of fishes.

\section{MATERIAL AND METHODS}

Seven juveniles of L. marmoratus previously breeded in captivity in CEPTA (Centro Nacional de Pesquisa e Conservação de Peixes Continentais, Pirassununga, SP, Brazil) and eight juveniles of the "cachandiá"hybrid (o P. reticulatum $\times \sigma^{7}$ L. marmoratus) were cytogenetical- ly analyzed in this study. Hybrids were artificially produced through hormonal induction of parental species with carp pituitary extract. Mitosis was stimulated as described by Oliveira et al. (1988), fishes were anesthetized with benzocaine and then euthanized and deposited in the fish collection at Laboratório de Genética de Peixes UNESP (Universidade Estadual Paulista Júlio de Mesquita Filho) (Bauru, SP, Brazil). Chromosome preparation and cytogenetic analysis were performed based on kidney cell suspensions basically according to Foresti et al. (1993). All fishes were previously identified with nuclear and mitochondrial species-specific molecular markers (Porto-Foresti et al. 2013) confirming them as pure L. marmoratus and the hybrid "cachandiá". Chromosomal preparations of $P$. reticulatum were obtained from Prado et al. (2012) and new metaphases were used for the study of the karyotype formulae and Argyrophilic nucleolus organizer regions (Ag-NORs)

Silver staining of the NOR was obtained following the technique of Howell and Black (1980). C-banding technique was applied according to Sumner (1972). Fluorescent in situ hybridization (FISH) was performed using $5 \mathrm{~S}$ rDNA probes based on genomic DNA of another Pimelodidae species, Pseudoplatystoma corruscans. The probe was obtained by PCR using the primers 5SA (5'-TCAACCAACCACAAAGACATTGGCAC-' 3 ) and 5SB (5'-TAGACTTCTGGGTGGCCAAAGGAATCA-'3) (Pendás et al. 1994). The PCR was performed in a total volume of $25 \mu \mathrm{L}$ and contained $150 \mu \mathrm{M}$ of dTTP, dGTP, and dCTP; $100 \mu \mathrm{M}$ of dATP; $1.5 \mathrm{mM} \mathrm{MgCl}$; $1 \mathrm{x}$ Taq buffer (20 mM Tris- $\mathrm{HCl}, \mathrm{pH} 8.4$ and $50 \mathrm{mM} \mathrm{KCl})$; 0.5 unit (U) of Taq Polymerase (Invitrogen); $0.2 \mu \mathrm{M}$ of each primer; and 10-50 ng of genomic DNA. Metaphases were hybridized as described by Pinkel et al. (1986). The probe was digoxigenin-11-dUTP labelled and hybridization signals were developed using antidigoxigenin-rhodamine. Cells in metaphase were posteriorly stained with 4',6-diamidino-2-phenylindole (DAPI). Karyotype images were captured digitally with a fluorescence microscope (Olympus BX50) and processed for contrast and luminosity using Adobe Photoshop CS5 software.

Chromosomal morphology was determined based on arm ratio, according to Levan et al. (1964), chromosomes were classified as metacentric (m), sub-metacentric (sm), sub-telocentric (st) and acrocentric (a), and arranged in decreasing size order for the karyotype organization. For the hybrid, chromosomes were not organized by pairs, but named with individual numbers (from 1 to 56) according to the morphology and also arranged in decreasing size order. 


\section{RESULTS}

L. marmoratus showed a diploid number of 56 chromosomes organized as $20 \mathrm{~m}+12 \mathrm{sm}+10 \mathrm{st}+14 \mathrm{a}$ (fundamental number $=98)($ Fig. 1A). Ag-NORs were located in the terminal region of the short arm of the sub-telocentric chromosome pair number 20 (Fig. 1A). P. reticulatum presented $2 \mathrm{n}=56$ chromosomes distributed in a karyotype of $20 \mathrm{~m}+12 \mathrm{sm}+12 \mathrm{st}+12$ a (fundamental number $=112)($ Fig. $1 \mathrm{C})$ and a single Ag-NOR stained in the short arm of the sub-telocentric pair number

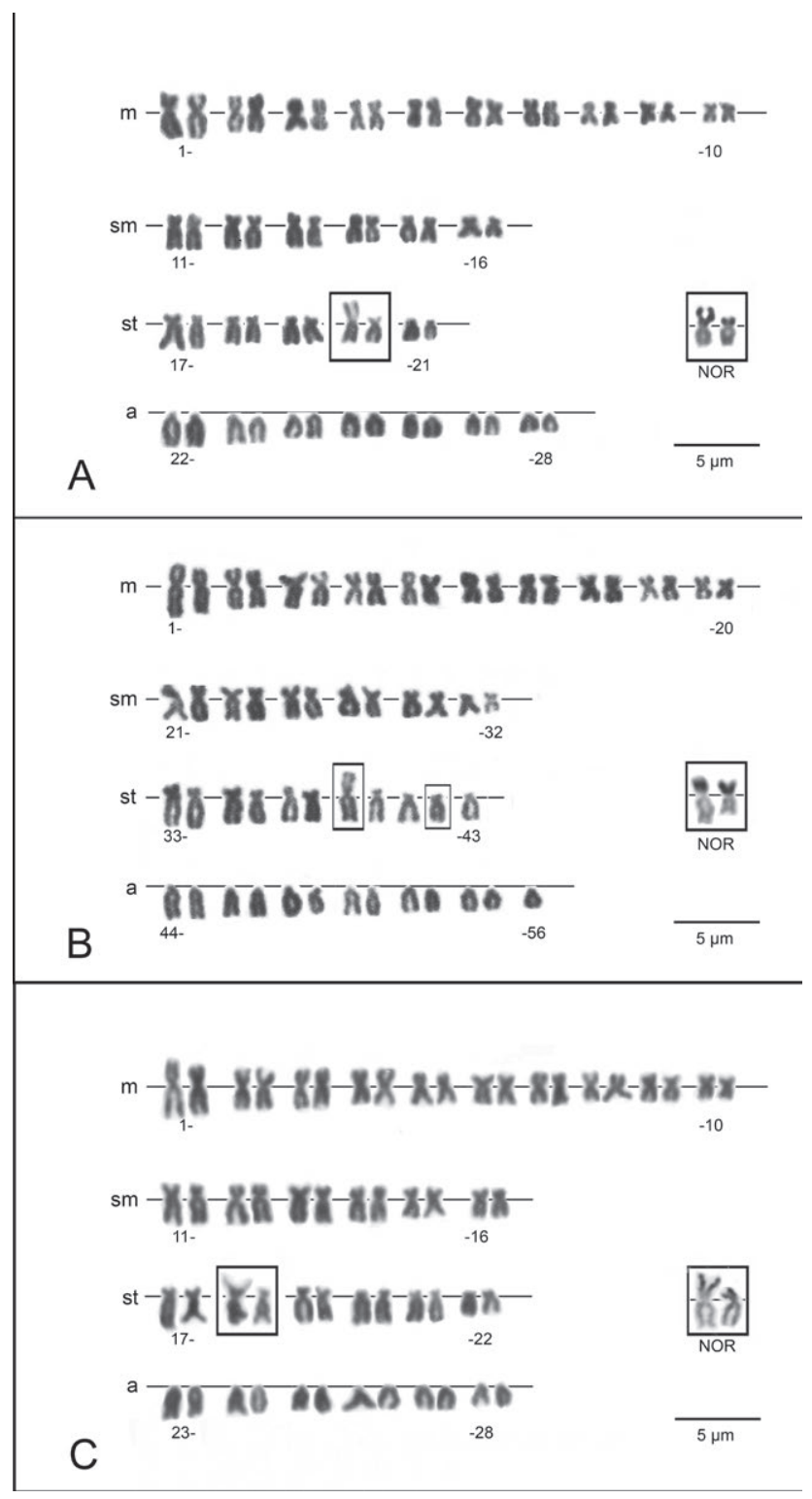

Figure 1. Karyotype of Leiarius marmoratus (A), the hybrid "cachandiá" (B) and Pseudoplatystoma reticulatum (C) after Giemsa staining. In the box, the NOR-bearing chromosomes.
18 (Fig. 1C). For both species, the Ag-NOR region was heteromorphic (Fig. 1A, 1C) and corresponding with a conspicuous secondary constriction when stained with Giemsa (Fig. 1A, 1C).

The hybrid presented a diploid number of 56 chromosomes, organized in a karyotype formula intermediate to the parental species, with $20 \mathrm{~m}+12 \mathrm{sm}+11 \mathrm{st}$ +13 a $(\mathrm{NF}=99)($ Fig. 1B). Two non-homologous subtelocentric chromosomes (39 and 42) of different sizes possessed Ag-NOR signals in the terminal region of the short arm (Fig. 1B). Nucleolar dominance was verified for all hybrid individuals (Table 1), counting a total of 154 metaphases presenting one active NOR (Fig. 2B) in contrast with 39 metaphases presenting Ag-NOR signals in two chromosomes (Fig. 2A). Results of nucleus analysis (Table 1) also showed a majority of cells presenting only one active Ag-NOR (115) (Fig. 3B) versus 37 nuclei

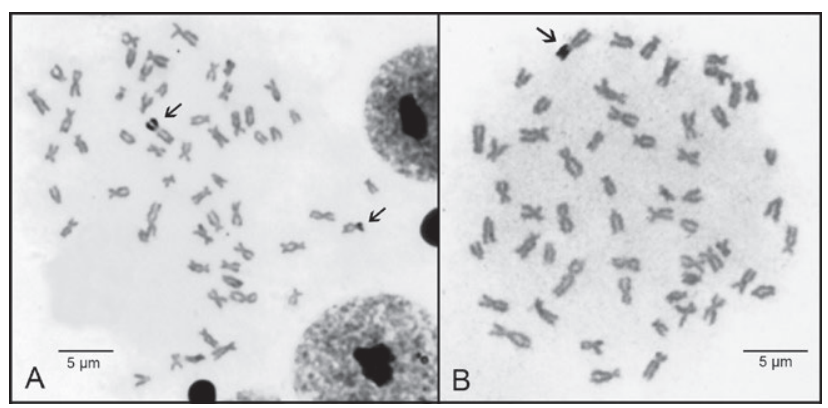

Figure 2. Metaphases of the hybrid "cachandiá" after Ag-NOR staining. In (A), a metaphase presenting two chromosomes of different sizes with Ag-NORs and (B) a metaphase with nucleolar dominance and only one Ag-NOR. Arrows indicates the NORbearing chromosomes.

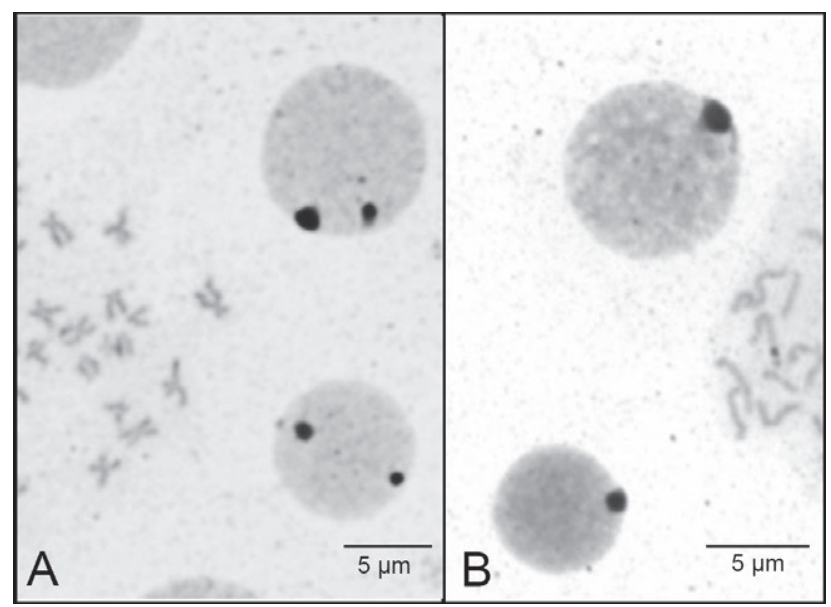

Figure 3. Nucleous of the hybrid "cachandiá" after Ag-NOR staining. In (A), nucleous presenting two Ag-NORs and (B) nucleous with only one Ag-NOR. 
Table 1. Number of metaphases and nucleus presenting one or two Ag-NORs for the hybrid "cachandiá".

\begin{tabular}{lcc}
\hline & Ag-NORs & Number \\
\hline \multirow{2}{*}{ Metaphases } & 1 & 154 \\
& 2 & 39 \\
Nucleus & 1 & 115 \\
& 2 & 37 \\
\hline
\end{tabular}

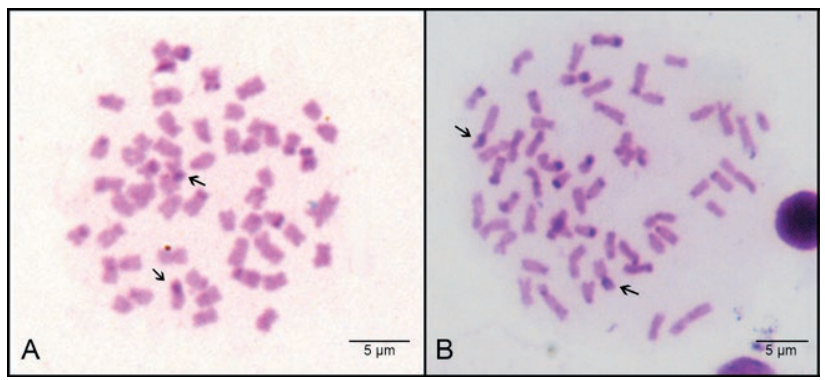

Figure 4. Metaphases of Leiarius marmoratus (A) and the hybrid "cachandiá" (B) after C-banding. Arrows indicate the putative NORbearing chromosomes.
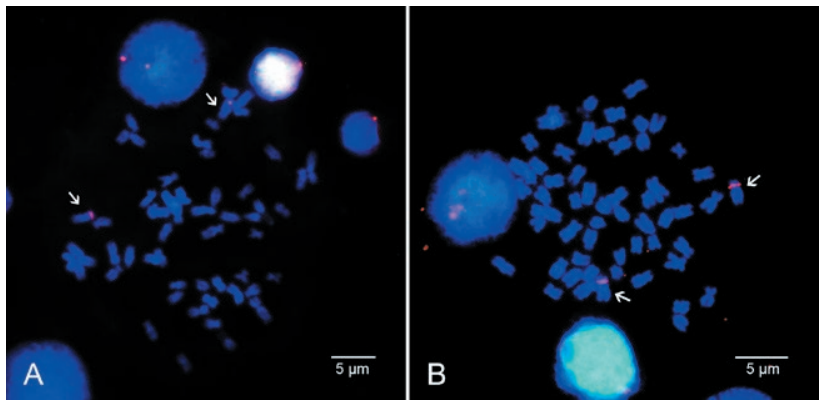

Figure 5 Metaphases of Leiarius marmoratus (A) and the hybrid "cachandiá" (B) after hybridization in situ with 5S rDNA. Arrows indicates the $5 \mathrm{~S}$ rDNA sites (red).

with two marks (Fig. 3A). Nucleolar dominance varied intraindividually, i.e., each individual presented both metaphases or nucleous with one or two active NORs.

Heterochromatic bands of L. marmoratus were located in the pericentromeric and terminal areas of some chromosomes and the Ag-NOR sites (Fig. 4A). For this species, $5 \mathrm{~S}$ rDNA sites were located at the pericentromeric region of the short arm of two sub-telocentric chromosomes, distinct from the Ag-NOR chromosome pairs that were identified by a secondary constriction (Fig. 5A). For the hybrid, C-bands marked the terminal and pericentromeric areas of some chromosomes as well as the NOR sites (Fig. 4B) and 5S rDNA hybridization signals were located in the terminal regions of two sub-telocentric chromosomes and were distinct from the NOR pair (Fig. 5B).

\section{DISCUSSION}

Conventional cytogenetics remains a powerful tool to characterize ichthyofauna biodiversity and to elucidate features of populations and species at the chromosomal level (Cioffi et al. 2018). The Neotropical region presents one of the most diverse ichthyofauna in the world (Reis et al. 2016), and the Amazonian Basin in special, harbors a rich variety of endemic fishes. In this region, Pimelodidae catfishes are very diverse, with species presenting the most diverse variations on body size, colours and ecological roles in the aquatic environment (Lundberg and Littmann, 2003). Despite that, a great amount of fish species has never been biologically or genetically studied. Recent findings showed efforts to cytogenetically characterize Pimelodidae species in the Amazonian region, providing important data for this group of fishes, as the described for Pimelodus (Fonseca et al 2018) and the giant catfishes Phractocephalus hemioliopterus (Swarça et al. 2017) and Brachyplatystoma filamentosum (Gonçalvez et al. 2014).

The present study describes the first cytogenetic description of L. marmoratus and contributes to characterize the rich biodiversity of Amazonian fishes. L. marmoratus shared cytogenetic characteristics commonly observed in Pimelodidae fishes as a diploid number of 56 chromosomes, a global pattern of heterochromatic bands distributed in terminal, peri and centromeric areas of the chromosomes, single Ag-NOR and 5S rDNA sites (Swarça et al. 2007, Nirchio et al. 2013; Swarça et al. 2017, Girardi et al. 2018). P. reticulatum presented the same chromosomal characteristics than previously described by Prado et al. (2012) and similar to other Pseudoplatystoma species as P. corruscans (Prado et al. 2012), P.metaense and P. orinocoense (Nirchio et al. 2013). The same conserved pattern of $2 \mathrm{n}=56$ chromosomes, single Ag-NOR and 5S rDNA sites was verified, supporting the close relationships within this group of fishes.

Pimelodidae family is characterized by a majority of species with conservative karyotypes which can be explained by the hypothesis that more dispersive and migratory species usually presents more stable karyotypes (Bertollo et al. 2017). This information corroborates the observed in this study for L. marmoratus and $P$. reticulatum, two large size catfishes presenting long distance reproductive migratory habits. 
Despite the conserved chromosomal characteristics, $L$. marmoratus and $P$. reticulatum showed variation in the karyotypic formula, with differences in the number of sub-telocentric and acrocentric chromosomes and the NOR-bearing chromosomes with a remarkable difference in size between the species. Variability in the karyotype formula without changes on the diploid number is a common feature in the Pimelodidae family, also verified for other Pseudoplatystoma species (Porto-Foresti et al. 2000; Nirchio et al. 2003) and among the Pimelodidae family (Swarça et al 2000), which can be explained by structural chromosomal rearrangements as pericentric inversions during their evolution and speciation events (Swarça et al. 2000; 2000)

A polymorphism of Ag-NOR marks between the homologous chromosomes were detected for L. marmoratus and $P$. reticulatum in this study (Fig. 1A, 1C - boxes), which is a relatively common feature observed for several groups of fishes including Characiformes (Vicari et al. 2006), Cypriniformes (Supiwong et al. 2012), Siluriformes (Swarça et al. 2005; Prado et al. 2012) and others fishes (Kasiroek et al. 2017). Differences in NOR size have been attributed to structural events such as chromosomal breaks, duplications of the ribosomal DNA clusters or differences in NOR activity. Association of NORs with secondary constrictions in the same chromosome region is also a common feature in fishes (Foresti et al. 1981, Feldberg and Bertollo 2014), also detected in this work for L. marmoratus and P. reticulatum. Data for other Pimelodidae species also related NOR polymorphisms as verified for $P$. metaense and $P$. orinocoense (Nirchio et al. 2013) with the NOR-bearing chromosome heteromorphic in size and correspondent with Ag-positive signals on the short arms of the chromosomes.

The "cachandiá" hybrid presented the same diploid number, similar $5 \mathrm{~S}$ rDNA bands and similar patterns of heterochromatin than the verified for L. marmoratus and $P$. reticulatum. This chromosomal pattern followed the previously observed for the parental species, which were apparently maintained in the hybrid. However, different karyotype formulae and chromosomes with Ag-NOR were observed for the hybrid. Hybrid chromosomes were organized in a karyotype intermediate to the parental species, formed by non-homologous chromosomes. The lack of homology could be clearly visualized by the chromosome number 11 (sub-telocentric) and the chromosome number 13 (acrocentric) (Fig. 1B), without their respective homologous pair, and the presence of Ag-NORs in two non-homologous chromosomes with a marked difference in size (39 and 42).

Cytogenetic is an important tool to discriminate hybrids from theirs parental species (Hashimoto et al.
2009) with applications for aquaculture and conservation. Chromosome morphology visualized by the karyotype, Ag-NORs, hibridization of rDNA genes or C-bands can be used as chromosome markers to identify species and hybrids and to elucidate chromosomal heritage in hybrids (Hashimoto et al. 2009). In this study, the intermediate karyotype of the hybrid "cachandiá" is probable insufficient to establish a precise chromosomal diagnosis since the differences between the chromosome types were very subtle and might vary in classifications according to chromosomal condensation. Conventional cytogenetic techniques as chromosomal morphology were also not sufficient to differentiate hybrids of $P$. reticulatum and $P$. corruscans (Prado et al. 2012). Otherwise, Ag-NORs were very specific for the hybrid, located in two non-homologous chromosomes different in size, allowing an accurate diagnosis of the hybrid. The presence of NORs in chromosomes with distinct morphology have been previously detected for hybrids of Pimelodus (Hashimoto et al. 2009) and a similar situation was observed for species of Cobitiis and their hybrids (Grabowska et al. 2019). A considerable number of metaphases or nucleolus with only one active NOR indicated dominant rDNA expression of one parental species in the hybrid, fact already described for other hybrid of fishes (Hashimoto et al., 2012; Prado et al., 2012).

Data obtained in this study may be valuable for hybrid identification in Brazilian aquaculture and suggested that Ag-NOR is a marker to identify the "cachandiá" hybrid by a simple and low-cost cytogenetic technique. Chromosomal data also contributes with novel information for the Amazonian catfish L. marmoratus to be future included in evolutionary and cytogenetic studies of Pimelodidae fishes.

\section{ACKNOWLEDGMENTS}

This work was supported by the Fundação de Amparo à Pesquisa do Estado de São Paulo (FAPESP) and Conselho Nacional de Desenvolvimento Científico e Tecnológico (CNPq).

\section{REFERENCES}

Bertollo LAC, Bello Cioffi M, Galetti Jr PM, Moreira Filho O. 2017. Contributions to the cytogenetics of the Neotropical fish fauna. Comp Cytogenet. 11: 665.

Buitrago-Suarez UA, Burr BM. 2007. Taxonomy of the catfish genus Pseudoplatystoma Bleeker (Siluriformes: 
Pimelodidae) with recognition of eight species. Zootaxa 1512: 1-38.

Campos JL. 2010. O cultivo do pintado (Pseudoplatystoma corruscans, Spix; Agassiz, 1829), outras espécies do gênero Pseudoplatystoma e seus híbridos. In: Baldisserotto B, Gomes LC, editors. Espécies nativas para a piscicultura no Brasil. 1st ed. Santa Maria (RS): Universidade Federal de Santa Maria; p. 335361.

Cioffi MB de, Moreira-Filho O, Ráb P, Sember A, Molina WF, Bertollo LAC. 2018. Conventional cytogenetic approaches - useful and indispensable tools in discovering fish biodiversity. Curr Genet Med Rep. 6: 176-186.

Coelho GCZ, Silva-Costa R, Porto-Foresti F, VerissimoSilveira R, Ninhaus-Silveira A. 2021. Comparative post-hatching ontogeny of Pseudoplatystoma reticulatum (Eigenmann and Eigenmann 1889) and Leiarius marmoratus (Gill, 1870) and their hybrid. J Appl Ichthyol. 00:1-13.

Feldberg E, Bertollo LAC. 1985. Nucleolar organizing regions in some species of Neotropical cichlid fish (Pisces, Perciformes). Caryologia. 38: 319-324.

Fonseca IC, Maciel LAM, Ribeiro FRV, Rodrigues LRR. 2018. Karyotypic variation in the long-whiskered catfish Pimelodus blochii Valenciennes, 1840 (Siluriformes, Pimelodidae) from the lower Tapajós, Amazonas and Trombetas Rivers. Comp Cytogenet. 12: 285.

Foresti F, Oliveira C, Almeida-Toledo LF. 1993. A method for chromosome preparations from large specimens of fishes using in vitro short treatment with colchicine. Experientia. 49: 810-813.

Foresti F, Toledo LA. 1981. Polymorphic nature of nucleolus organizer regions in fishes. Cytogenet Genome Res. 31: 137-144.

Girardi SC, Pavanelli CS, Margarido VP. 2018. Contributions to the systematic of Pimelodidae (Osteichthyes, Siluriformes): basic and molecular cytogenetics on seven species of Pimelodus from three Brazilian hydrographic systems. Neotrop Ichthyol. 16: e170148.

Gonçalves ALM, Prado FDD, Ferreira DC, Voltolin TA, Senhorini JA, Foresti F, Porto-Foresti F. 2014. First cytogenetic characterization of the giant Amazonian catfish Brachyplatystoma filamentosum (Siluriformes, Pimelodidae). Caryologia. 67: 101-105.

Grabowska AI, Boroń A, Kirtiklis L, Spóz A, Juchno D, Kotusz J. 2019. Chromosomal inheritance of parental rDNAs distribution pattern detected by FISH in diploid $\mathrm{F}_{1}$ hybrid progeny of Cobitis (Teleostei, Cobitidae) species has non-Mendelian character. J Fish Biol. 96: 261-273.
Hashimoto DT, Laudicina A, Bortolozzi J, Foresti F, Porto-Foresti F. 2009. Chromosomal features of nucleolar dominance in hybrids between the Neotropical fish Leporinus macrocephalus and Leporinus elongatus (Characiformes, Anostomidae). Genetica. 137: 135140.

Hashimoto DT, Prado FD, Foresti F, Porto-Foresti F. 2016. Molecular identification of intergenus crosses involving catfish hybrids: risks for aquaculture production. Neotrop Ichthyol. 14: e150139.

Hashimoto DT, Senhorini JA, Foresti F, Porto-Foresti F. 2012. Interspecific fish hybrids in Brazil: management of genetic resources for sustainable use. Rev Aquac. 4: 108-118.

Howell WM, Black DA. 1980. Controlled silver-staining of nucleolus organizer regions with a protective colloidal developer: a 1-step method. Experientia. 36: 1014-1015.

Kasiroek W, Indananda C, Pinthong K, Supiwong W, Pengseng P, Tanomtong A. 2017. NOR Polymorphism and chromosome analysis of banggai cardinalfish, Pterapogon kauderni (Perciformes, Apogonidae). Cytologia. 82: 17-23.

Kubitza F, Ono EA, Campos JL. 2011. Alguns destaques da piscicultura em 2011. Revista Panorama da Aquicultura 21: 14-23.

Levan A, Fredga KE, Sandberg HA. 1964. Nomenclature from centromeric position on chromosomes. Hereditas. 52: 201-220.

Lundberg JG, Littmann MW. 2003. Pimelodidae (Longwhiskered catfishes). In: Reis RE, Kullander SO and Ferraris CJ Jr, editors. Checklist of the Freshwater Fishes of South and Central America. 1st ed. Porto Alegre (RS): EDIPUCRS, p. 432-446.

Mateo FJ, Delgado N, López H. 2008. Caracterización morfométrica del híbrido Yaque pintado (Pseudoplatystoma Fasciatum x Leiarius Marmoratus) y sus progenitores (Siluriformes: Pimelodidae). Revista de la Facultad de Ciencias Veterinarias. 49: 047-060.

Nirchio M, Mujica A, Oliveira C, Granado A, Mora J, Hett AK, Rossie AR, Milana V, Sola L. 2013. Pseudoplatystoma metaense and P. orinocoense (Siluriformes: Pimelodidae) from the Orinoco basin, Venezuela: cytogenetic and molecular analyses. Ital J Zool. 80: 526-535.

Oliveira C, Almeida-Toledo LF, Foresti F, Toledo-Filho SA. 1988. Supernumerary chromosomes, Robertsonian rearrangements and multiple NORs in Corydoras aeneus (Pisces, Siluriformes, Callichthyidae). Caryologia. 41: 227-236.

Pendas AM, Moran P, Freije JP, Garcia-Vazquez E. 1994. Chromosomal mapping and nucleotide sequence of 
two tandem repeats of Atlantic salmon 5S rDNA. Cytogenet Cell Genet. 67: 31-36.

Pinkel D, Straume T, Gray JW. 1986. Cytogenetic analysis using quantitative, high-sensitivity, fluorescence hybridization. Proc Nat Acad Sci. 83: 2934-2938.

Porto-Foresti F, Andreatas AA, Oliveira C, Foresti F. 2000. The karyotype of Pseudoplatystoma fasciatum (Teleostei, Siluriformes) from the Rio Paraguay basin. Chromosome Sci. 4: 99-102.

Porto-Foresti F, Hashimoto DT, Prado FD, Senhorini JA, Foresti F. 2013. Genetic markers for the identification of hybrids among catfish species of the family Pimelodidae. J Appl Ichthyol. 29: 643-647.

Prado FD, Nunes TL, Senhorini JA, Bortolozzi J, Foresti F, Porto-Foresti F. 2012. Cytogenetic characterization of $F_{1}, F_{2}$ and backcross hybrids of the Neotropical catfish species Pseudoplatystoma corruscans and Pseudoplatystoma reticulatum (Pimelodidae, Siluriformes). Genet Mol Biol. 35: 57-64.

Sumner AT. 1972. A simple technique for demonstrating centromeric heterochromatin. Exp Cell Res. 75: 304-306.

Supiwong W, Tanomtong A, Supanuam P, Jantarat S, Khakhong S, Sanoamuang LO. 2012. A discovery of nucleolar organizer regions (NORs) polymorphism and karyological analysis of Smith's barb, Puntioplites proctozysron (Cypriniformes, Cyprinidae) in Thailand. Cytologia. 77: 35-42.

Swarça AC, Caetano LG, Dias AL. 2000. Cytogenetics of species of the families Pimelodidae and Rhamdiidae (Siluriformes). Genet Mol Biol. 23: 589-593.

Swarça AC, Dias AL, Fenocchio AS. 2017. Cytogenetic studies in the redtail catfish, Phractocephalus hemioliopterus (Bloch \& Schneider, 1801) (Siluriformes, Pimelodidae) a giant fish from Amazon basin. Comp Cytogenet. 11: 119-128.

Swarça AC, Fenocchio AS, Cestari MM, Dias AL. 2008. Analyses of the structure of NORs in two species of South American Sorubiminae fishes (Siluriformes) by means of several cytogenetic techniques. Folia boil. 56: 31-35.

Swarça AC, Fenocchio AS, Dias AL. 2007. An update cytogenetic review for species of the family Pseudopimelodidae, Pimelodidae and Heptapteridae (Pisces, Siluriformes). Suggestion of a cytotaxonomical classification. Caryologia. 60: 338-348.

Swarça, A. C., Orsi, M. L., Takagui, F. H., Dias, A. L., Dergam, J. A., \& Fenocchio, A. S. (2018). First chromosome data on Steindachneridion doceanum (Siluriformes: Pimelodidae): a critically endangered catfish endemic of the Doce River basin, Brazil. Neotropical Ichthyology, 16(4).
Vicari MR, Almeida MCD, Bertollo LAC, Moreira-Filho O, Artoni RF. 2006. Cytogenetic analysis and chromosomal characteristics of the polymorphic $18 \mathrm{~S}$ rDNA in the fish Prochilodus lineatus (Characiformes, Prochilodontidae). Genet Mol Biol. 29: 621625.

Yabu MHS, Vidotto-Magnoni AP, Casimiro ACR, Garcia DAZ, Costa ADA, Prado FD, Porto-Foresti F, Orsi ML. 2018. First record of non-native hybrid catfish Pseudoplatystoma reticulatum $\times$ Leiarius marmoratus in the Upper Paraná River basin, Brazil. J Fish Biol. 92: 261-267. 